\title{
A comparison of chromosome characters in three species of Thymus (Lamiaceae) collected in Russia and Mongolian Altai
}

\author{
Tsuneo Funamoto ${ }^{1,7}$, Katsuhiko Kondo ${ }^{2,3}$, Sergey V. Smirnov ${ }^{4}$, Irina V. Tatarenko ${ }^{5}$, \\ Tsuyoshi Motohashi ${ }^{3}$ and Oyunchimeg Damdinsuren ${ }^{6}$ \\ ${ }^{1}$ Biological Institute, Fundamental Education and Research Center of \\ Pharmaceutical Sciences, Showa Pharmaceutical University, \\ 3-chome, Higashi-Tamagawagakuen, Machida City, Tokyo 194-8543, Japan; \\ ${ }^{2}$ Laboratory of Plant Chromosome and Gene Stock, Graduate School of Science, \\ Hiroshima University, Higashi-Hiroshima City 739-8526, Japan; \\ ${ }^{3}$ Laboratory of Plant Genetics and Breeding Science, Agriculture Course, \\ Faculty of Agriculture, Tokyo University of Agriculture, \\ 1737 Funako, Atsugi City 243-0034, Japan; \\ ${ }^{4}$ Department of Plant Systematics and South-Siberian Botanical Garden, \\ Altai State University, Barnaul 656099, Russia; \\ ${ }^{5}$ Reserch and Education Center of Population Biology, Moscow State Pedagogical University, \\ Kibalchich St. 6, kor 5, Moscow 129278, Russia; \\ ${ }^{6}$ Biology Division, Hovd State University, Hovd City, \\ Hovd Province, Mongolia \\ ${ }^{7}$ Author for correspondence: (funamoto@ac.shoyaku.ac.jp) \\ Received March 6, 2008; accepted April 10, 2008
}

\begin{abstract}
Characters of the resting, the mitotic prophase and metaphase chromosomes in three species of Thymus were studied. The species studied had commonly resting chromosomes of the complex chromocenter type and mitotic prophase chromosomes of the proximal type. Thymus mongolicus showed the chromosome numbers of $2 \mathrm{n}=26$ and 27 and T. przewalskii and T. roseus showed the chromosome number of $2 \mathrm{n}=26$. The chromosome number of $2 \mathrm{n}=26$ for T. przewalskii and that of $2 \mathrm{n}=27$ for $T$. mongolicus were reported here for the first time and that of $2 \mathrm{n}=26$ for T. roseus and T. mongilicus verified the previous reports. The chromosome number of $2 \mathrm{n}=27$ for T. mongolicus seemed to have one $\mathrm{B}$-chromosome as $2 \mathrm{n}=26+1 \mathrm{~B}$ with respect to the existence of a peculiar heteropycnotic body at resting stage and high pollen stainability. Three species were commonly placed in the diploid level if the basic chromosome numbers of $\mathrm{x}=13$ was accepted. Their karyotypes at mitotic metaphase were quite similar to each other regarding chromosome sizes, chromosome types according to the centromeric position and mono-modality of chromosome lengths from the longest to the shortest chromosomes except for satellite sizes.
\end{abstract}

KEYWORDS: Chromosome character, Lamiaceae, Mongolia, Russia, Thymus

Thymus L., the Lamiaceae (Labiatae) is small subshrub plants and consists of approximately 400 species (Willis 1982). They are distributed in the temperate zone of the Eurasian continent, mainly in the Mediterranean region (Willis 1982) and grow in diabase, serpentine and calcareous rocks, limestone, in cracks rocks, on a bank, steppe, on sandy soils, xerophilous grassland, on loessic slopes and along road sides. Thymus has always been taxonomically problematic group and views concerning the taxonomic definition of the forms are extremely varied. It produces some natural hybrids. Plants of the genus is often cultivated and propagate to extract the aromatic ethereal oil and flavouring.

The first cytological observation in Thymus was counting and documenting the chromosome number: $2 \mathrm{n}=24$ in T. serpyllum reported by Löve and Löve (1942). Then, many more researchers have found at least 50 different chromosome numbers from $2 \mathrm{n}=14$ of $T$. seravschanicus to $2 \mathrm{n}=90$ of $T$. zygioides var. lycaonicus. They also have found aneuploidy in $T$. longedentatus as well as autoploidy in about 170 taxa included 139 species, 17 subspecies, 12 varieties and two hybrids by Löve and Löve (1942), Saaremaa (1947), Jalas (1948), Jalas and
Kaleva (1966, 1967), Trela-Sawicka (1968, 1970, 1972), Gogina and Svetozarova (1972), Gurzenkov (1972), Lee (1972), Jalas and Uotila (1976), Krogulevich (1978), Arrigonia et. al. (1980), Bir and Saggoo (1980), ElenaRoselló (1980), Morales Valverde (1980, 1986 1986a, 1990), Astanova (1981), Hruška and Bellomaria (1982), Fernandes and Leitao (1984), Funamoto et. al. (1993), Markova and Goranova (1994), Mártonfi and Mártonfiova (1996), Boscaiu et al. (1998), Tahiri et al. (1998), Constantinidis et al. (2002). Jalas (1948), Jalas and Kalev (1967) and Mártonfi and Mártonfiova (1996) and Mehrpure et al. (2002) have discussed chromosomal evolution of Thymus regarding their basic chromosome numbers.

This paper reports on chromosome characters of the resting, mitotic prophase and metaphase chromosomes in three species of Thymus collected in Russia and Mongolia by our field expedition.

\section{Materials And Methods}

Plant materials Eleven plants of Thymus mongolicus (Ronn.) Ronn., T. przewalskii (Kom.) Nakai and T. roseus Schipcz. (=T. serpyllum L.) were collected in three sites in Russia and Mongolian Altai (Table 1). They were 
Table 1. Collection sites, sample and chromosome numbers in three species of Thymus observed

\begin{tabular}{|c|c|c|c|}
\hline Species & Collection site & $\begin{array}{l}\text { Sample } \\
\text { number }\end{array}$ & $\begin{array}{l}\text { Chromosome } \\
\text { number }(2 n)\end{array}$ \\
\hline \multirow[t]{2}{*}{ T. mongolicus (Ronn.) Ronn. } & \multirow{2}{*}{$\begin{array}{l}\text { Mongolia, Bayan-Ulgii Province, Bayan-Ulgii-Aimak, Lake side } \\
\text { of Eli-Hur, } 48^{\circ} 35^{\prime} 52^{\prime \prime} \mathrm{N}, 090^{\circ} 00^{\prime} 24 \text { " E, alt. 2,070 m. }\end{array}$} & 1 & 26 \\
\hline & & 2 & 27 \\
\hline T. przewalskii (Kom.) Nakai & $\begin{array}{l}\text { Russia, Primorye Territory, Kankaiskiy District, west shore of } \\
\text { Khanka Lake, } 4 \text { km from Turiy Rog City, } 45^{\circ} 11^{\prime} 87^{\prime} \text { N, } 131^{\circ} 59^{\prime} \\
85^{\prime} \text { E, alt. } 76 \text { m. }\end{array}$ & 3 & 26 \\
\hline $\begin{array}{l}\text { T. roseus Schipcz. } \\
\text { (=T. serpyllum L.) }\end{array}$ & $\begin{array}{l}\text { Russia, Altai Territory, Altai Republic, Onguday District, the Chuya } \\
\text { river joins the Katun river, } 50^{\circ} 23^{\prime} 75^{\prime \prime} \mathrm{N}, 088^{\circ} 40^{\prime} 39^{\prime \prime} \mathrm{E} \text {, alt. } 780 \mathrm{~m} \text {. }\end{array}$ & 5 & 26 \\
\hline
\end{tabular}

brought back to Japan and cultivated in unglazed flowerpots in shade place in the experimental garden of Showa Pharmaceutical University.

Taxonomic treatments followed Czerepanov (1995) and Doron'kin (2006). The voucher specimens were deposited in Funamoto's personal herbarium in Showa Pharmaceutical University.

Observation of chromosomes Freshly growing root-tips were collected from the above plants. They were cut off $5-10 \mathrm{~mm}$ long and pretreated in 2mM 8-hydroxyquinoline at about $20^{\circ} \mathrm{C}$ for $4 \mathrm{~h}$, and then, fixed in $45 \%$ acetic acid for $10 \mathrm{~min}$ at ca $2^{\circ} \mathrm{C}$. They were macerated in a mixture of $1 \mathrm{~N}$ hydrochloric acid and $45 \%$ acetic acid (1:1) for 20$23 \mathrm{sec}$ at about $60^{\circ} \mathrm{C}$, and stained with $2 \%$ aceto-orcein for about $30 \mathrm{~min}$ at room temperature in a moist chamber with $45 \%$ acetic acid. Slide preparations were made with the conventional squash methods. The slides were faintly heated under alcohol frame for 1-2 sec before observation. Pollen grains were stained with $2 \%$ aceto-orcein to count at least first 1,000 grains for pollen stainability.

Crassification for the chromosome types at resting and mitotic prophase stages followed Tanaka (1971, 1977). Crassification for the chromosome types by the centromeric positions at mitotic metaphase stage followed Levan et al. (1964). Measurements of chromosome lengths made in good mitotic metaphase cells.

\section{Results And Discussion}

Thymus mongolicus (Ronn.) Ronn., T. przewalskii (Kom.) Nakai and T. roseus Schipcz. (synonym $T$. serpyllum L.) had common chromosomal characters such as the complex chromocenter type of the resting chromosomes, which had numerous chromomeric granules, fibrous threads and chromatin blocks and the small chromatin blocks were irregular in shape and varied in number (Fig. 1a, e, h and k), and the proximal type of mitotic prophase chromosomes, which had the early condensed segments confined to the proximal regions of both short and long arms or only the short arm, showing clear condensation transition from the proximal to the distal regions (Fig. 1b, f, i and 1). The mitotic metaphase chromosomes of the three species studied had commonly small sized chromosomes and mono-modality of the chromosome lengths from the longest to the shortest chromosomes, and thus, formed similar karyotypes to each other (Table 2; Fig. 2).

Thymus mongolicus is distributed in Kazakhstan, Siberia in Russia, Mongolia and North Central and North East in China. Three plants of this species were collected on a cracks rocks in Bayan-Ulgii Province, Mongolia (Table 1). One of them had the chromosome number of $2 n=26$ (Fig. 1c and d) and the other two plants had $2 n=27$ (Fig. 1g). The first report on the chromosome number of $2 \mathrm{n}=26$ in Thymus was made in T. pseudo-allicus by Jalas and Kaleva (1966). The chromosome number of $2 n=26$ in T. mongolicus in the present study verified the previous report by Doron'kin (2006). Thus, the chromosome number of $2 n=27$ documented here was very first report for this species. In the resting nuclei in the two plants which showed the chromosome number of $2 n=27$, peculiarly a large condensed heteropycnotic bock (Fig. 1e) was found. However, such a large heteropycnotic block has never been seen in the resting nucleus in the plant with the chromosome number of $2 n=26$ (Fig. 1a). The plants with the chromosome numbers of $2 n=26$ and 27 had a high pollen stainabilities with $93.46 \%$ and $90.27 \%$, respectively. Following these characters in the resting chromosomes and the pollen stainability the chromosome number of $2 \mathrm{n}=27$ could be constituted by $2 \mathrm{n}=26+1 \mathrm{~B}$. Thymus mongolicus must be a diploid if the basic chromosome number of $\mathrm{x}=13$ was accepted.

The plants with $2 \mathrm{n}=26$ showed the chromosome sizes ranged from 1.5 to $1.0 \mu \mathrm{m}$ long and total $30.6 \mu \mathrm{m}$ long averaged $1.2 \mu \mathrm{m}$ long, and the karyotype of mediancentromeric and submedian-centromeric chromosomes (Fig. 2a and b; Table 2). In contrast, the plants with $2 n=27$ showed the chromosome sizes ranged from 1.5 to $0.9 \mu \mathrm{m}$ long and total $31.7 \mu \mathrm{m}$ long averaged $1.17 \mu \mathrm{m}$ long, and the karyotype of median-centromeric and submedian-centromeric chromosomes (Fig. 2c and d; Table 2). A small dot-shaped satellite was rarely observed on medium or small sized chromosome.

Thymus przewalskii is distributed in Far East Russia and North Central, North East and South East in China. Three plants of this species were collected in a bank on the shore of Lake Hanka in Primorye Territory, Russia (Table 1), and showed commonly the chromosome 


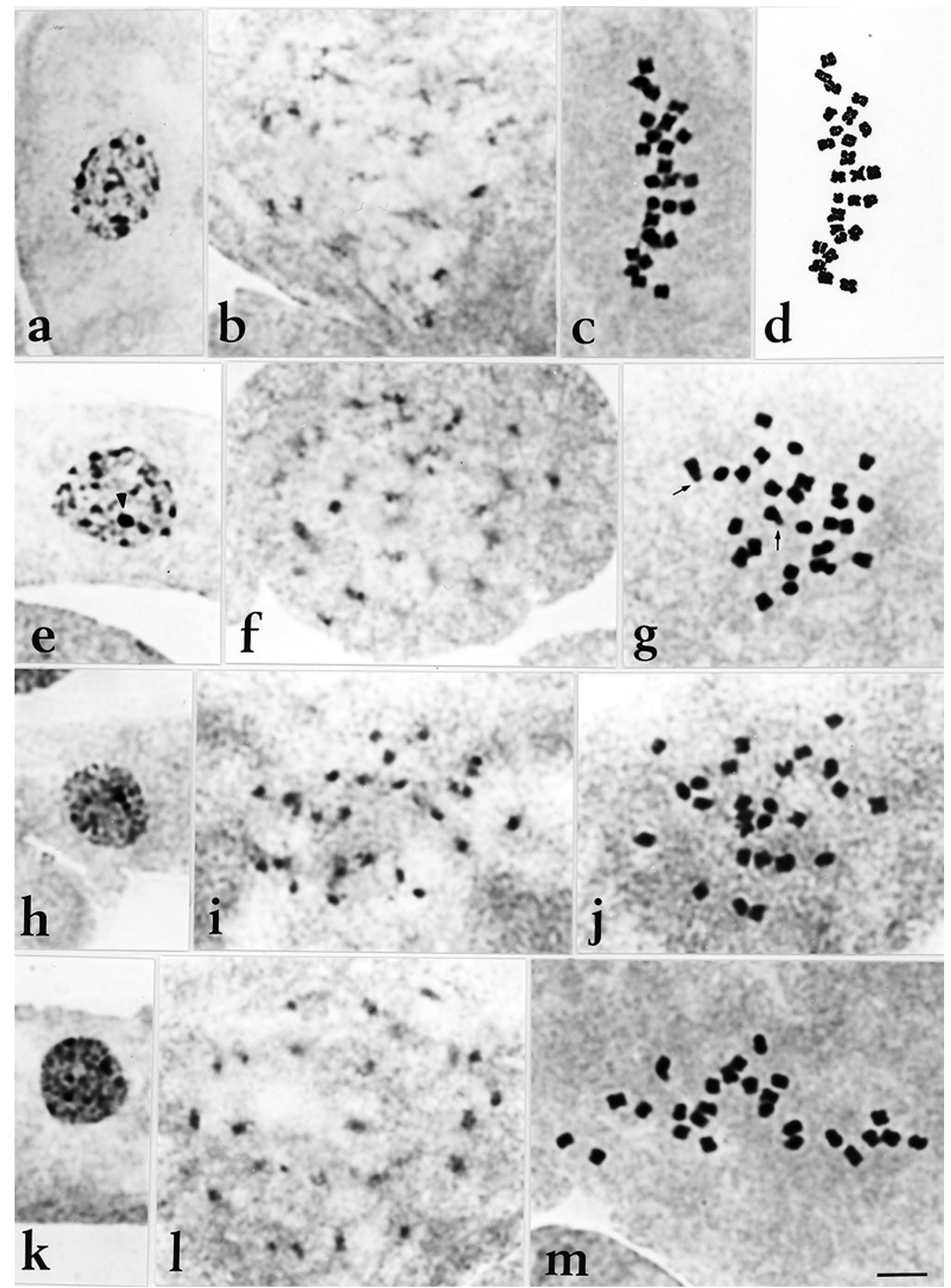

Fig. 1. Karyomorphological comparisons of three species of Thymus. a-d. T. mongolicus $(2 \mathrm{n}=26)$. e-g. T. mongolicus $(2 \mathrm{n}=27)$. $\mathrm{h}-\mathrm{j}$. T. przewalskii $(2 \mathrm{n}=26) . \mathrm{k}-\mathrm{m}$. T. roseus $(2 \mathrm{n}=26) . \mathrm{a}, \mathrm{e}, \mathrm{h}$ and $\mathrm{k}$. Resting chromosomes. b, f, i and 1 . Somatic prophase chromosomes. c, d, g, j and $\mathrm{m}$. Mitotic metaphase chromosomes. Arrows indicate satellites and arrows head represent B-chromosome. $\mathrm{d}$ is the drawing of the photograph $\mathrm{c}$. Bar $=3 \mu \mathrm{m}$.

number of $2 \mathrm{n}=26$ (Fig. $1 \mathrm{j}$ ) that was reported here for the first time. This species could be diploid if the basic chromosome number of $\mathrm{x}=13$ was accepted. The chromosome sizes of this species ranged from 1.5 to 0.9 $\mu \mathrm{m}$ long and total $31.3 \mu \mathrm{m}$ long averaged $1.2 \mu \mathrm{m}$ long, and the karyotype of median-centromeric and submedian-centromeric chromosomes (Fig. 2e and f;
Table 2). The small dot-shaped satellite was rarely observed in medium or small sized chromosomes.

Thymus roseus $(=$ Th. serpyllum) is widely distributed in Europe, Mediterranean and Asian continent. Five plants of this species were collected in a locality, on calcareous rocks in Altai Republic in Altai Territory, Russia (Table 1), and showed commonly the chromosome 
Table 2. Karyotype comparisons of three species of Thymus observed

\begin{tabular}{|c|c|c|c|c|c|c|c|}
\hline \multirow[b]{2}{*}{ Species } & \multirow[b]{2}{*}{$\begin{array}{c}\text { Chromosome } \\
\text { number }\end{array}$} & \multicolumn{6}{|c|}{ Chromosome length $(\mu \mathrm{m})$} \\
\hline & & $\begin{array}{l}\text { Cell } \\
\text { No. }\end{array}$ & $\begin{array}{l}\text { The longest } \\
\text { Mean } \pm \text { SD } \\
\text { (Ranges) }\end{array}$ & $\begin{array}{c}\text { The shortest } \\
\text { Mean } \pm \text { SD } \\
\text { (Ranges) }\end{array}$ & $\begin{array}{c}\text { Total } \\
\text { Mean } \pm \text { SD } \\
\text { (Ranges) }\end{array}$ & $\begin{array}{l}\text { Average } \\
\text { Mean } \pm \text { SD } \\
\text { (Ranges) }\end{array}$ & Form \\
\hline T. mongolicus & $2 n=26$ & 4 & $\begin{array}{l}1.5 \pm 0.21 \\
(1.6-1.3)\end{array}$ & $\begin{array}{l}1.0 \pm 0.07 \\
(1.0-0.9)\end{array}$ & $\begin{array}{c}30.6 \pm 3.52 \\
(33.7-27.5)\end{array}$ & $\begin{array}{c}1.2 \pm 0.14 \\
(1.3-1.06)\end{array}$ & $\mathrm{m}+\mathrm{sm}$ \\
\hline T. mongolicus & $2 n=27$ & 11 & $\begin{array}{l}1.5 \pm 0.13 \\
(1.6-1.2)\end{array}$ & $\begin{array}{l}0.9 \pm 0.09 \\
(1.1-0.8)\end{array}$ & $\begin{array}{c}31.7 \pm 2.87 \\
(36.2-27.7)\end{array}$ & $\begin{array}{c}1.17 \pm 0.11 \\
(1.34-1.03)\end{array}$ & $\mathrm{m}+\mathrm{sm}$ \\
\hline T. przewalskii & $2 n=26$ & 7 & $\begin{array}{l}1.5 \pm 0.08 \\
(1.6-1.4)\end{array}$ & $\begin{array}{l}1.0 \pm 0.05 \\
(1.0-0.9)\end{array}$ & $\begin{array}{c}31.3 \pm 0.78 \\
(32.0-29.7)\end{array}$ & $\begin{array}{c}1.2 \pm 0.03 \\
(1.23-1.14)\end{array}$ & $\mathrm{m}+\mathrm{sm}$ \\
\hline $\begin{array}{l}\text { T. roseus } \\
(=\text { T. serpyllum })\end{array}$ & $2 n=26$ & 12 & $\begin{array}{l}1.4 \pm 0.11 \\
(1.6-1.3)\end{array}$ & $\begin{array}{l}0.9 \pm 0.05 \\
(1.0-0.9)\end{array}$ & $\begin{array}{c}30.0 \pm 1.72 \\
(32.9-28.2)\end{array}$ & $\begin{array}{c}1.15 \pm 0.07 \\
(1.27-1.08)\end{array}$ & $\mathrm{m}+\mathrm{sm}$ \\
\hline
\end{tabular}

SD: standard deviation. m: median-centromeric chromosome, sm: submedian-centromeric chromosome

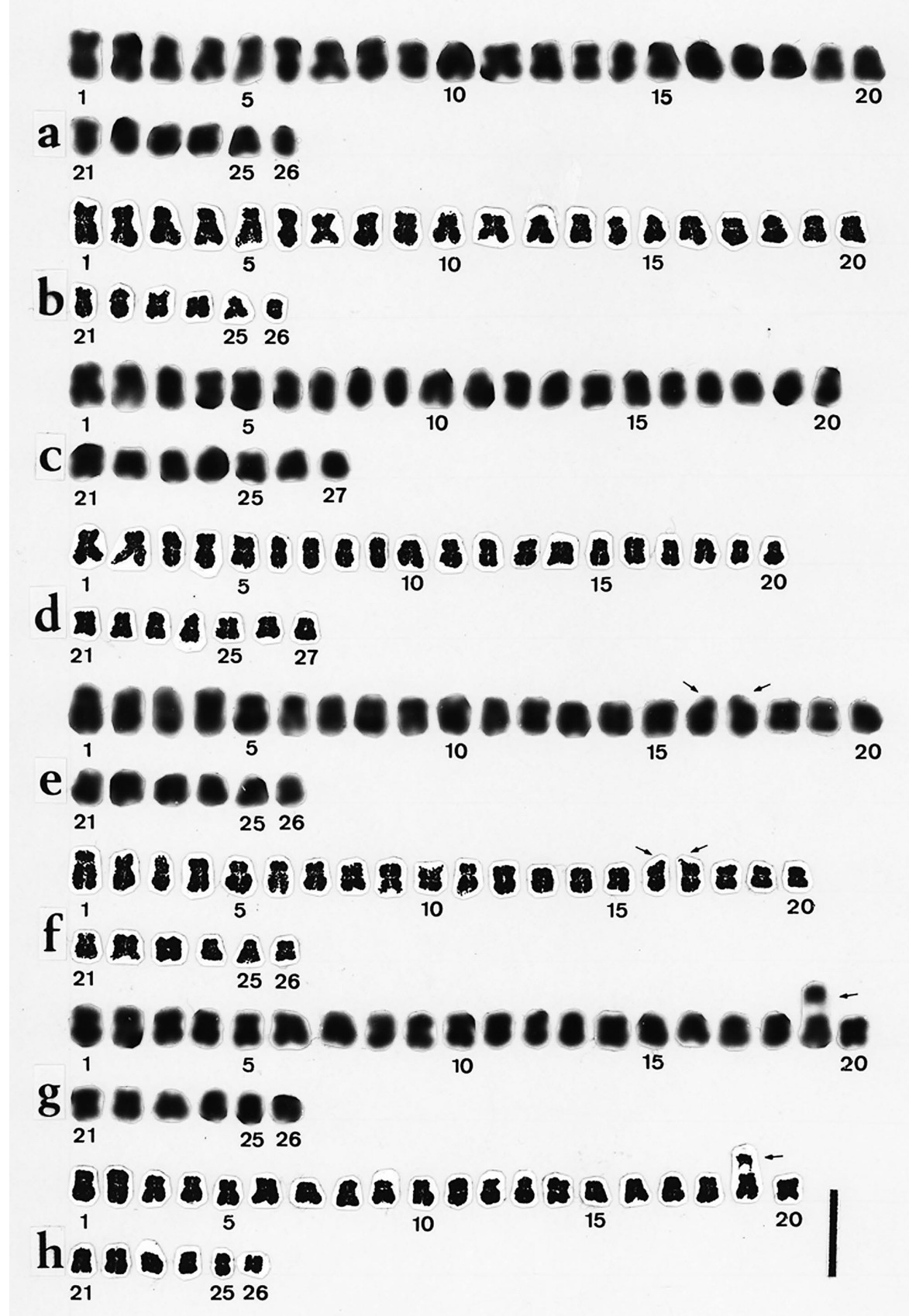

Fig. 2. Karyotypes of three species of Thymus. a-d. T. mongolicus. e-f. T. przewalskii. $\mathrm{g}$-h. T. roseus. b, d, f and $\mathrm{h}$ are the drawings of the photographs a, c, e and $\mathrm{g}$, respectively. Arrows point satellites. Bar $=3 \mu \mathrm{m}$. 
number of $2 \mathrm{n}=26$ (Fig. $1 \mathrm{~m}$ ). This chromosome numbers of this species were previously reported as $2 n=24$ and 50 by Löve and Löve (1942), Jalas (1948), Krogulevich (1978), Mártonfi and Mártonfiova (1996), Lövkvist and Hultgård (1999), and $n=12$ and 13 by Bir and Saggoo (1980) and Gill (1984). This species could be a diploid if the basic chromosome number of $\mathrm{x}=13$ was accepted. The chromosome sizes of this species ranged from 1.4 to $0.9 \mu \mathrm{m}$ long and total $30 \mu \mathrm{m}$ long averaged $1.15 \mu \mathrm{m}$ long, and the karyotype of median-centromeric and submedian centromeric chromosomes (Fig. $2 \mathrm{~g}$ and h; Table 2). A little large dot-shaped satellite was rarely observed in medium or small sized chromosomes.

Three species of Thymus observed had very similar chromosomal characters in resting and mitotic prophase and metaphase chromosomes and basic chromosome number except for satellite sizes.

The lowest chromosome number of $2 \mathrm{n}=14$ for Thymus was reported in T. seravschanicus by Astanova (1981) and thus, the basic chromosome number of $x=13$ shown in the present three species might be secondary basic number if we accepted chromosomal evolutions proposed by Gill (1981).

ACKNOWLEDGEMENTS. We are indebted to Dr. Valentina P. Verkholat for identification of collected plants, arrangements and guiding of our field trips in Primory Territory in Russia. This study was financially supported by the Grant-in-Aid for the Scientific Program (A) 19255004 (Representative: Katsuhiko Kondo) of Japan Society for the Promotion of Science.

\section{Literature Cited}

Arrigoni, P. V., Giannerini, M. and Mori, B. 1980. Numeri cromosomici per la Flora Italiana: 714-721. Inform. Bot. Ital. 12: 137-143 (in Italian).

Astanova, S. B. 1981. Novye dannye o khromosomnikh chislakh vidov gubocvetnykh Tadzhikistana. Izv. Akad. Nauk Tdziksk. SSR, Otd. Biol. Nauk (Dushanbe) 1 (82): 10-15 (in Russian).

Bir, S. S. and Saggoo, M. I. S. 1980. In Chromosome number reports LXIX. Taxon 29: 711-712.

Boscaiu, M., Riera, J., Estrelles, E. and Güemes, J. 1998. Chromosome numbers of several Lamiaceae from Spain. Folia Geobotanica 33: 187-199.

Constantinidis, T., Bareka, E. P. and Kamari, G. 2002. Karyotaxonomy of Greek serpentine angiosperms. Bot. Jour. Linn. Soc. 139: 109-124.

Czerepanov, S. K. 1995. Thymus L., p. 302-304. In: Vascular plants of Russia and adjacent states (the former USSR). Cambridge University Press, U.S.A.

Doron'kin, V. M. 2006. Thymus L. p. 225-242. In: L. J. Malyaschev, Ed., Flora of Siberia Vol. 11 PyrolaceaeLamiaceae (Labiatae). Science Publishers, U.S.A.

Elena-Roselló, J. A. 1980. Contribución al estudio cariológico de los tomillos españoles. Anales Jard. Bot. Madrid 37: 113-115 (in Spanish with English abstract).

Fernandes, A. and Leitao, M. T. 1984. Contribution a l'etude cytotaxinomique des Spermatophyta du Portugal XVIII - Lamiaceae. Mem. Soc. Brot. 27: 27-75 (in Spanish).

Funamoto, T., Shoge, K., Habu, S. and Nakamura, T. 1993. A karyomorphological comparison of Thymus serphyllum subsp. quinquecostatus and T. vulgaris. La Kromosomo II-70: 2417-2421.
Gill, L. S. 1981. Chromosomal evolution and incidence of polyploidy in the Canadian labiatae. Rev. Cytol. Biol. Veg. Bot. 4: 331-339.

Gill, L. S. 1984. The incidence of polyploidy in the WestHimalayan Labiatae. Rev. Cytol. Biol. Veg. Bot. 7: 5-16.

Gogina, E. E. and Svetozarova, V. V. 1972. On the systematics and karyology of some species of Thymus Section Subbracteati Klok. Bull. Glav. Bot. Sad (Moscow) 84: 36-41 (in Russian).

Gurzenkov, N. N. 1972. Studies of chromosome numbers of plants from the south of the Soviet Far East. Komarov Lectures 20: 47-61 (in Russian with English summary).

Hruška, K. and Bellomaria, B. 1982. Numeri cromosomici per la Flora Italiana: 877-881. Inform. Bot. Italia 14: 238-242 (in Italian).

Jalas, J. 1948. Chromosome studies in Thymus I. Somatic chromosome numbers with special reference to the Fennoscandian forms. Hereditas 34: 414-434.

Jalas, J. and Kaleva, K. 1966. Chromosome studies in Thymus L. (Labiatae). IV. Mitotic numbers of some Balkan, Transylvanian and South Alpine taxa. Ann. Bot. Fenn. 3: 123-127.

Jalas, J. and Kaleva, K. 1967. Chromosome studies in Thymus L. (Labiatae). V. Ann. Bot. Fenn. 4: 74-80.

Jalas, J. and Uotila, M. 1976. Chromosome studies in Thymus L. (Labiatae). VI. Counts on Macedonian and Thracian taxa. Ann. Bot. Fenn. 13: 61-64.

Krogulevich, R. E. 1978. Karyological analysis of the species of the flora of eastern Sayan. p. 19-48. In: L. I. Malyshev and G. A. Peshlcova, Eds., Flora of the Prebaikal, Novosibirsk. (in Russian).

Lee, Y. N. 1972. Chromosome Number of Flowering Plants in Korea (4). J. Korean Res. Inst. Better Living 8: 41-51.

Levan, A., Fredga, K. and Sandberg, A. A. 1964. Nomenclature for centromeric position on chromosomes. Hereditas 52: 201-220.

Löve, A. and Löve, D. 1942. Cyto-taxonomic studies on Boreal plants. I. Some observations on Swedish and Icelandic plants. Kungl. Fysiogr. Sallsk. Lund. Forh., 12, Nr. 6, 1-19.

Lövkvist, B. and Hultgård, U. M. 1999. Chromosome numbers in south Swedish vascular plants. Opera Bot. 137: 1-42.

Markova, M. and Goranova, V. 1994. Mediterranean chromosome number reports 4 (240-266). Fl. Medit. 4: 233-254.

Mártonfi, P. and Mártonfiova, L. 1996. Thymus chromosome numbers from Carpathians and Pannonia. Thaiszia Jour. Bot. Kosice 6: 25-38.

Mehrpure, S., Mirzaie-Nodushan, H., Majd, A. and Sefidkon, F. 2002. Karyotypic studies of two Thymus species. Cytologia 67: 343-346.

Morales Valverde, R. 1980. Numeros cromosomaticos especies Ibericas del genero Thymus L. (Labiatae). Anales Jard. Bot. Madrid 36: 339-348 (in Spanish with English abstract)

Morales Valverde, R.1986. Taxonomía de los géneros Thymus (excludia la sección Serphyllum) y Thymbra encla Península Ibérica. Ruizia 3: 1-324 (in Spanish).

Morales Valverde, R. 1986a. Notas citotaxonomicas sobre algunos tomillos Ibericos y Norteafricanos (Thymus L. Labiatae). Anales Jard. Bot. Madrid 43: 35-41 (in Spanish with English abstract).

Morales Valverde, R. 1990. Números cromosomáticos de plantas occidentals, 582-590. Anales Jard. Bot. Madrid 47: 193-198 (in Spanish).

Morton, J. K. 1973. A cytological study of the British Labiatae (excluding Mentha). Watsonia 9: 239-246.

Tahiri, B., Rejdali, M. and Atbib, M. 1998. Contribution à l'étude caryologique de certaines espèces marocaines du genre Thymus L. (Labiatae). Flora Mediterranea 8: 41-47 (in Spanish with English abstract). 
Tanaka, R. 1971. Types of resting nuclei in Orchidaceae. Bot. Mag. Tokyo 84: 118-122.

Tanaka, R. 1977. Recent karyotype study. pp. 293-326. In Ogawa, K., Kurozumi, K., Koike, S. and Sato, S. Eds., Plant cytology. Asakura Book, Tokyo (in Japanese).

Trela-Sawicka, Z. 1968. Cytological investigations in the genus Thymus L. Acta Biol. Cracov. Ser. Bot. 11: 59-69.

Trela-Sawicka, Z. 1970. Chromosome numbers of five species of Thymus L. from Slovakia. Acta Biol. Cracov.
Ser. Bot. 13: 125-132.

Trela-Sawicka, Z. 1972. Further cytological studies in the genus Thymus L. from Poland. Acta Biol. Cracov. Ser. Bot. 15: 61-68.

Vaarama, A. 1947. Some chromosome numbers in the genera Angelica, Ocimum, Satureja, Thymus and Cnicus. Archivum Soc. Zool. Bot. Fenn. Vanamo 2: 55-59.

Willis, J. C. 1982. A Dictionary of the Flowering Plants and Ferns. R. P. S. Gahlot for International Book, Delhi. 